\title{
Calonectria (Cylindrocladium) Leaf Spot of Palm¹
}

\author{
Jiaming Yu and Monica L. Elliott ${ }^{2}$
}

\section{Introduction}

Calonectria is a fungus that affects a large number of hosts worldwide, including timber and ornamental, agricultural, and horticultural crops, causing a wide range of disease symptoms, such as cutting rot, damping-off of seedlings, leaf spot, shoot blight, and root rot. While Calonectria can cause damping-off of palm seedlings, the primary disease it causes in palms is a leaf spot. In general, all palms could be potential hosts for this leaf spot disease, especially in container or field nurseries where palms are grown in close proximity to each other. Seedling and juvenile palms (immature palms without trunks) seem to be most susceptible to this leaf spot disease.

\section{Pathogen and Hosts}

Calonectria is the name given to the teleomorph (sexual stage) of this fungal genus. The anamorphs (asexual stage) of all species of this fungus are Cylindrocladium spp., and it is this stage that is most often observed. Ca. colhounii $(=C y$. colhounii), Ca. ilicicola (= Cy. parasiticum), Ca. indusiata (= $C y$. theae), and Ca. pteridis (=Cy. pteridis) are the pathogens that usually cause leaf spots and blights on palms in the continental United States. Although disease symptoms are indistinguishable, all four species produce conidia (asexual spores) and conidiophores (spore-bearing structures) that distinguish them from each other. The conidiophore axis is elongate with a vesicle at the end. The shape and size of the vesicle help to identify the species.
In the United States, Calonectria has been reported to cause disease on palms in Florida, Hawaii, Louisiana, North Carolina, Oregon, South Carolina, Tennessee, and Virginia. Affected species include Chamaedorea elegans (parlor palm), C. cataractarum (cat palm), Cocos nucifera (coconut palm), Dypsis lutescens (golden cane palm or areca palm), Dictyosperma album (princess palm), Howeae belmoreana (Belmore sentry palm), H. forsteriana (Kentia palm), Laccospadix australasica (Atherton palm), Livistona chinensis (Chinese fan palm), Ravenea rivularis (majesty palm), Syagrus romanzoffiana (queen palm), Washingtonia filifera (California or desert fan palm), and W. robusta (Mexican fan palm). It is likely that more palm species are susceptible than just these but have not been reported. Also, there are non-palm hosts of Calonectria, many of which are ornamentals.

\section{Symptoms and Disease Development}

Disease symptoms start as flecks of small, water-soaked lesions and then transition to irregular shades of gray, yellow, reddish brown, brown, or black (Figs. 1 and 2). Usually, newly developed leaf spots are brown, circular, and $<1 \mathrm{~mm}$ in diameter. Old leaf spots are nearly circular or elliptical, up to 3-5 $\mathrm{mm}$. As lesions expand, they are tan or gray in the center and surrounded by a brownish edge or halo (Figs. 1-3). As the disease progresses, the lesions become larger and more irregular; the rachis and petiole may also be infected with similar flecks. Eventually, leaflets or entire leaves desiccate because of lesion expansion (Figs. 4 and 5).

1. This document is PP302, one of a series of the Plant Pathology Department, Florida Cooperative Extension Service, Institute of Food and Agricultural Sciences, University of Florida. Original publication date January 2013. Visit the EDIS website at http://edis.ifas.ufl.edu.

2. Jiaming Yu, graduate student, and Monica L. Elliott, professor, Plant Pathology Department, Fort Lauderdale Research and Education Center, Florida Cooperative Extension Service, Institute of Food and Agricultural Sciences, University of Florida, Gainesville, FL 32611. 


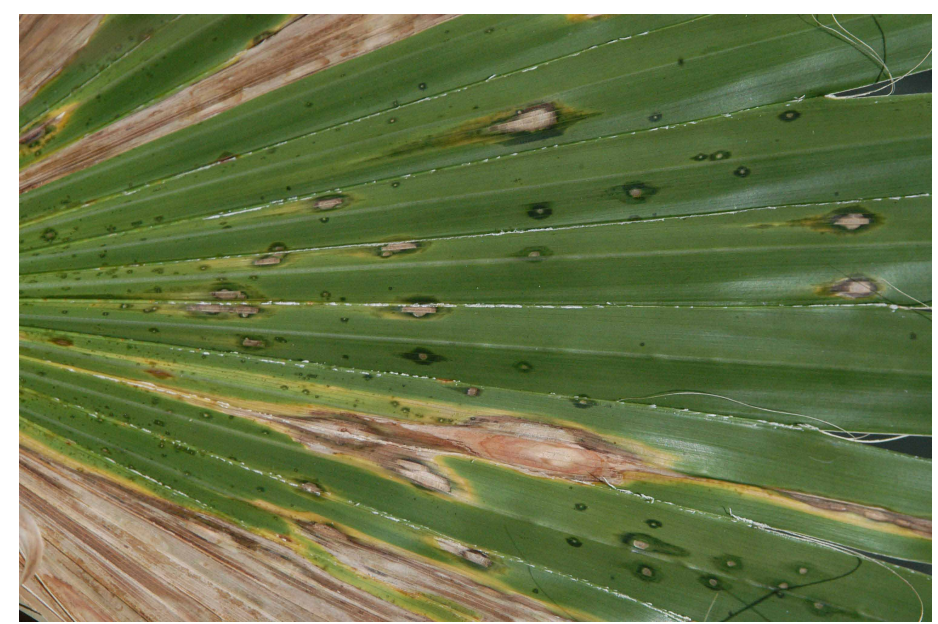

Figure 1. Washingtonia filifera leaf exhibiting multiple stages of leaf spot development, from beginning pinpoint water-soaked lesions to expansive necrotic areas.

Credits: M. L. Elliott

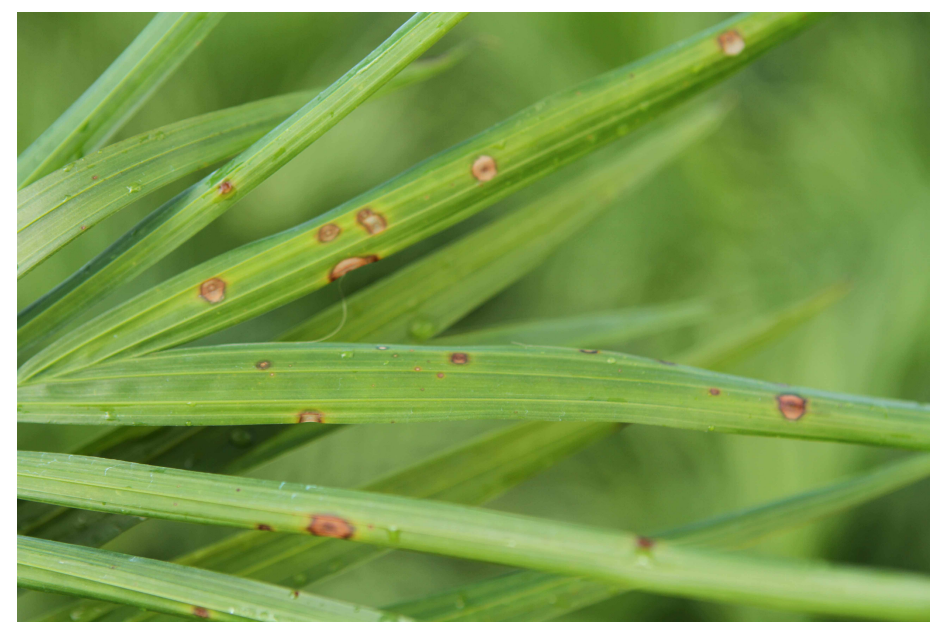

Figure 2. Ravenea rivularis leaves exhibiting leaf spots in early stages of development.

Credits: I. Maguire

Leaf spots usually appear on leaves of all ages, although fully expanded, mature leaves seem to be most susceptible. When the spots are discretely separated from each other by green tissue, the disease is called a leaf spot. In contrast, when these spots expand and merge together, it is referred to as leaf blight.

In general, the anamorph (or conidial) stage is involved with the disease cycle; however, some plants are also infected by ascospores (teleomorph stage). Insects, pruning, handling, air, rain, or irrigation water can spread conidia; ascospores could be released from perithecia and be spread by air movement. Ascospores and conidia located on host tissue germinate under conditions of high humidity or surface moisture (Fig. 6). The perithecia are usually formed on infected plant tissue. The fungus first produces conidiophores and then forms conidia on the tissue surface.

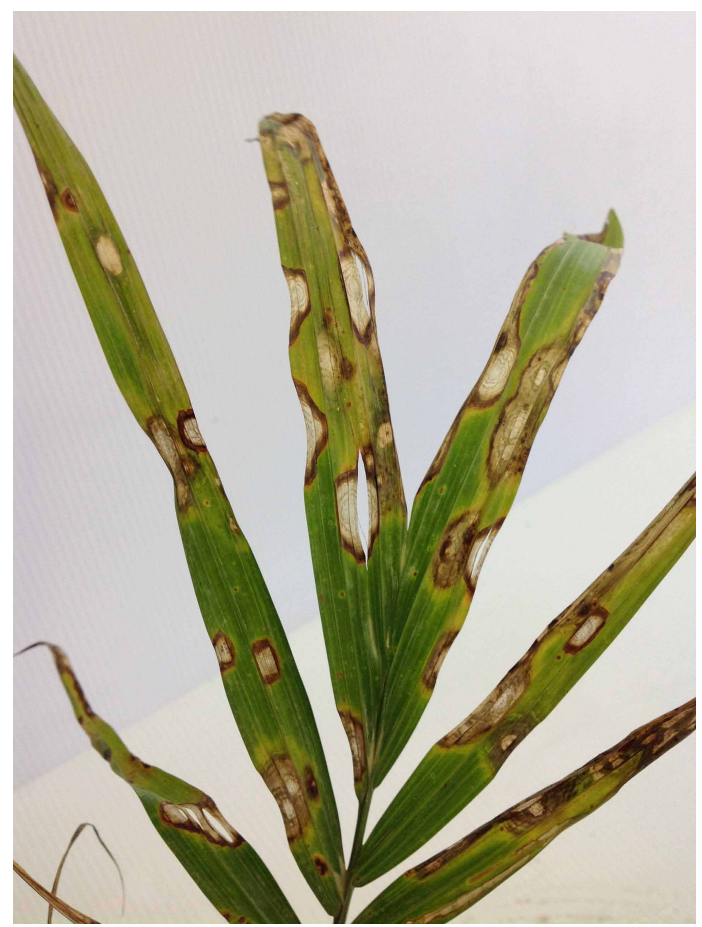

Figure 3. Chamaedorea cataractarum leaf with expansive necrotic lesions.

Credits: I. Maguire

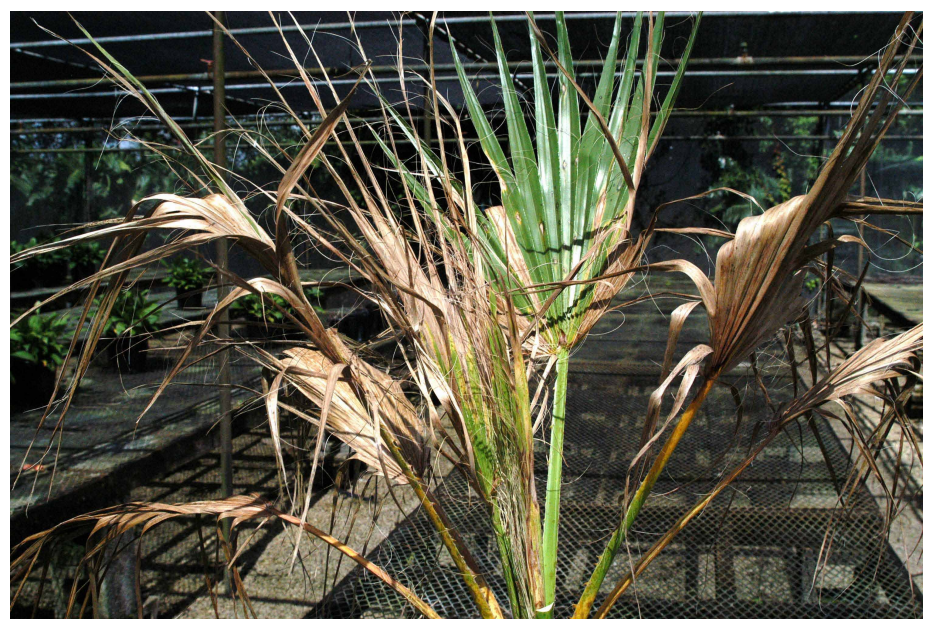

Figure 4. All the older leaves of this Washingtonia filifera have died because of Calonectria leaf spot. The youngest, fully expanded leaf is declining, and even the spear leaf is being affected as it emerges. Credits: M. L. Elliott

\section{Diagnosis}

Potassium deficiency symptoms (on old leaves) and manganese deficiency symptoms (on new leaves) have similar patterns compared with leaf spots, appearing as black spots and necrotic streaks, respectively. See Nutrient Deficiencies of Landscape and Field-Grown Palms in Florida (http://edis. ifas.ufl.edu/EP273).

Besides Calonectria spp., there are other pathogens that cause leaf spots on palms, such as Annellophora, Bipolaris, Cerospora, Colletotrichum, Exserohilum, Gliocladium, 


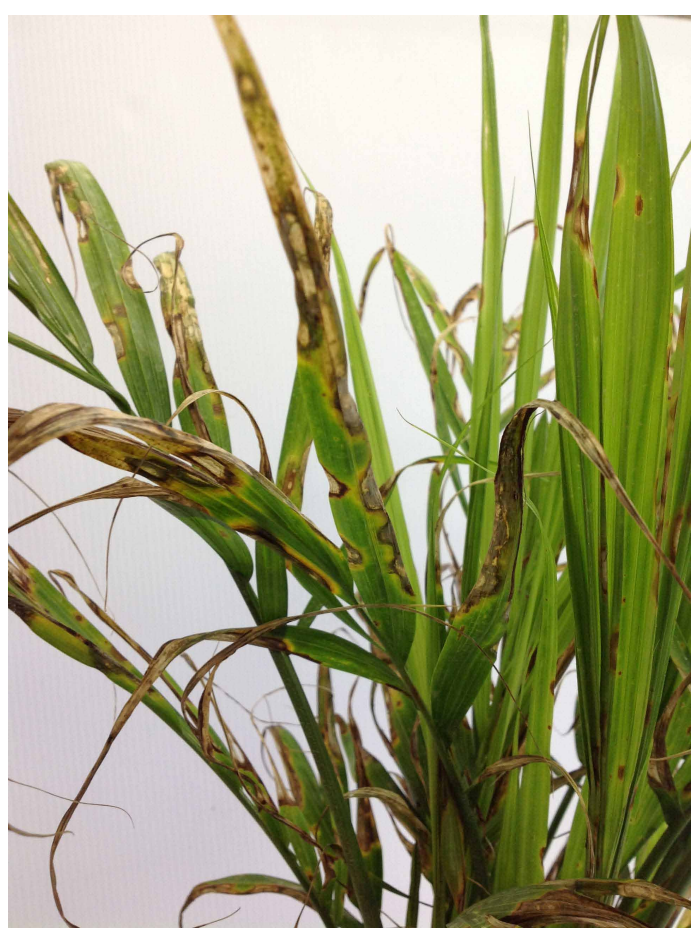

Figure 5. Chamaedorea cataractarum severely affected by Calonectria leaf spot as lesions merge together to kill leaflets and eventually entire leaves.

Credits: M. L. Elliott

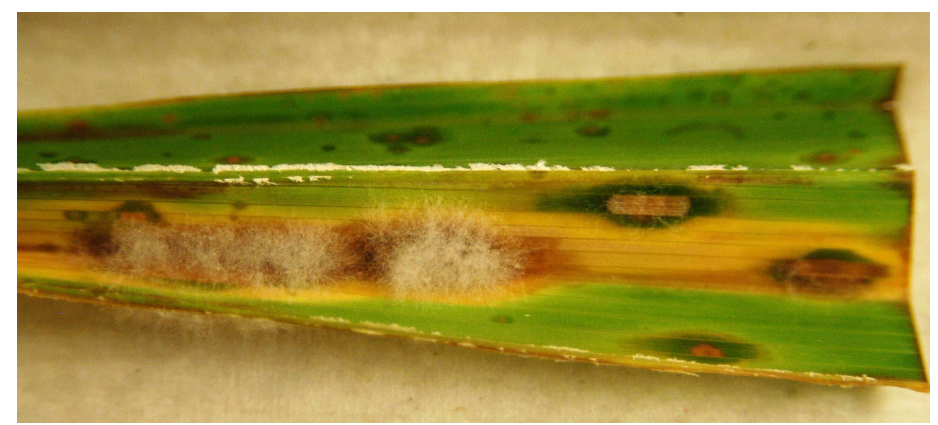

Figure 6. Mycelia of the fungus Cylindrocladium (= Calonectria) is growing from the leaf spot on this Washingtonia robusta leaf. Conidial spores develop from the mycelia and then spread to other nearby palms to begin new infections.

Credits: M. L. Elliott

Pestalotiopsis, Pestalotia, Phaeotrichoconis, Phyllachora, Pseudocerospora, and Stigmina. See Leaf Spots and Leaf Blights of Palm (http://edis.ifas.ufl.edu/PP142). Diagnosis is further complicated by the fact that leaf symptoms look similar no matter which fungus is actually causing the symptoms. Therefore, determining if Calonectria (= Cylindrocladium) is the cause of the leaf spot symptoms observed requires observation of the spores, either directly on the palm leaf tissue or in culture, after the fungus has been isolated from the leaf tissue.

The Florida Extension Plant Diagnostic Clinic (FEPDC) (http://www.plantclinic.org) is available for pathogen identification. Contact your local county Extension office (http://ifas.ufl.edu/extension-offices-rec-maps.shtml) or FEPDC for details on sample submission and cost of a laboratory diagnosis.

\section{Control}

Most leaf diseases occur on seedling or juvenile palms in nurseries, which can have hundreds of palms spaced closely together. This situation increases humidity among plants and also increases the movement of the pathogens from infected to healthy plants by reducing the distance that spores need to travel in order to infect a new plant. Therefore, increasing space between plants can improve plant health by decreasing pathogen infection.

Another critical part of leaf spot management is moisture control. High humidity and moisture create favorable conditions for spore germination and dissemination. Increased air circulation keeps leaf tissue dry and helps prevent infection. Other ways to limit humidity and moisture include avoiding wet leaves at night by irrigating in the early morning hours just before dawn (so leaves dry quickly), eliminating overhead irrigation, or growing palms in covered greenhouses. Make sure larger plants are not blocking air movement to smaller plants.

Constant monitoring for leaf diseases is also important. Since the disease develops quickly, it is important to notice early symptoms as soon as possible to limit the spread to other plants. With container-grown palms, action should be taken to eliminate the infected plant as soon as possible in order to suppress or prevent further spread of the disease. In field nurseries or in the landscape, infected leaves should be removed from the plant and from the field or landscape. Do not leave infected leaves on the ground below the palm. Also be aware of potential alternate hosts if the palms are grown in a mixed pattern with other plants.

Numerous fungicides are labeled for control of Calonectria and Cylindrocladium, but fungicides should not be used as the only management tool. They should always be used in combination with the cultural controls described above. Fungicides should be applied to palms after diseased palms or diseased leaf tissues have been removed. Even with systemic fungicides, apply the products uniformly to the leaf tissue. Fungicides should always be applied in accordance with the directions on the label to be in compliance with federal laws. 


\section{Selected References}

Crous, P. W., J. Z. Groenewald, J.- M. Risede, P. Simoneau, and K. D. Hyde. 2006. "Calonectria Species and Their Cylindrocladium Anamorphs: Species with Clavate Vesicles.” Studies in Mycology 55: 213-226.

Crous, P. W., J. Z. Groenewald, J.- M. Risede, P. Simoneau, and N. L. Hywel-Jones. 2004. "Calonectria Species and Their Cylindrocladium Anamorphs: Species with Sphaeropedunculate Vesicles." Studies in Mycology 50: 415-430.

Elliott, M. L. 2012. Leaf Spots and Leaf Blight of Palms. PP-218. Gainesville: University of Florida Institute of Food and Agricultural Sciences. http://edis.ifas.ufl.edu/PP142.

Elliott, M. L., T. K. Broschat, J. Y. Uchida, and G. W. Simone. 2004. Compendium of Ornamental Palm Disease and Disorders. St. Paul, MN: American Phytopathological Society.

Lombard, L., P. W. Crous, B. D. Wingfield, and M. J. Wingfield. 2010. "Species Concepts in Calonectria (Cylindrocladium).” Studies in Mycology 66: 1-14.

Uchida, J. Y., M. Aragaki, and R. Y. Iwata. 1989. Calonectria Leaf Spot of Forster Sentry Palm. Brief No. 077. Honolulu: University of Hawaii, Hawaii Institute of Tropical Agriculture and Human Resources. 